\title{
Benthic grazing in a eutrophic river: cascading effects of zoobenthivorous fish mask direct effects of herbivorous fish
}

\author{
Madlen Gerke ${ }^{\text {Corresp.. }}{ }^{1}$ ， Daniel Cob Chaves ${ }^{1}$, Marc Richter ${ }^{1}$ ， Daniela Mewes ${ }^{1}$, Jörg Schneider ${ }^{2}$, Dirk Hübner ${ }^{3}$ \\ , Carola Winkelmann ${ }^{1}$ \\ ${ }^{1}$ Institute for Integrated Natural Sciences, University of Koblenz-Landau, Koblenz, Rhineland-Palatinate, Germany \\ 2 Bürogemeinschaft für fisch- und gewässerökologische Studien, Frankfurt, Hesse, Germany \\ 3 Bürogemeinschaft für fisch- und gewässerökologische Studien, Marburg, Hesse, Germany \\ Corresponding Author: Madlen Gerke \\ Email address: mgerke@uni-koblenz.de
}

Benthic grazing strongly controls periphyton biomass. The question therefore arises whether benthic grazing could be used as a tool to reduce excessive growth of periphyton in nutrient-enriched rivers. Although benthic invertebrate grazers reduce the growth of periphyton, this is highly context dependent. Here we assessed whether the only obligate herbivorous fish in European rivers, the common nase (Chondrostoma nasus L.), is able to reduce periphyton biomass in a eutrophic river. We conducted three consecutive in situ experiments at low, intermediate and high densities of nase in the river using standard tiles on the river bottom naturally covered with periphyton that were accessible to fish and tiles that excluded fish foraging with electric exclosures. The biomass of benthic invertebrate grazers was very low relative to nase. We hypothesised that nase would reduce periphyton biomass on accessible tiles and therefore expected higher periphyton biomass on the exclosure tiles, at least at intermediate and high densities of nase in the river. Contrary to our expectation, the impact of fish grazing was low even at high fish density, as judged by the significantly lower chlorophyll a concentration on exclosure tiles even though the ash-free dry mass on accessible and exclosure tiles did not differ. The lower chlorophyll a concentrations on exclosure tiles might be explained by a higher biomass of invertebrate grazers on the exclosure tiles, which would indicate that the effect of invertebrate grazers was stronger than that of herbivorous fish grazers. The high biomass of invertebrate grazers on exclosure tiles likely arose from the exclusion of zoobenthivorous fish, which occur in the river at high densities. The results of our smallscale experiments suggested that cascading top-down effects of zoobenthivorous fish have a higher impact on periphyton biomass than direct effects of herbivorous nase. 


\section{Benthic grazing in a eutrophic river: cascading effects of zoobenthivorous fish 2 mask direct effects of herbivorous fish}

3

4 Madlen Gerke ${ }^{1}$, Daniel Cob Chaves ${ }^{1}$, Marc Richter ${ }^{1}$, Daniela Mewes ${ }^{1}$, Jörg Schneider ${ }^{2}$, Dirk

5 Hübner $^{3}$, Carola Winkelmann ${ }^{1}$

6

$7 \quad{ }^{1}$ University of Koblenz-Landau, Institute for Integrated Natural Sciences, Koblenz, Germany

$8 \quad{ }^{2}$ Bürogemeinschaft für fisch- und gewässerökologische Studien, Frankfurt, Germany

$9 \quad{ }^{3}$ Bürogemeinschaft für fisch- und gewässerökologische Studien, Marburg, Germany 10

11

12

13

14 Corresponding author:

15

16 Madlen Gerke ${ }^{1}$

17

18 Email address: mgerke@uni-koblenz.de

19 


\section{Abstract}

21 Benthic grazing strongly controls periphyton biomass. The question therefore arises whether benthic grazing could be used as a tool to reduce excessive growth of periphyton in nutrientenriched rivers. Although benthic invertebrate grazers reduce the growth of periphyton, this is highly context dependent. Here we assessed whether the only obligate herbivorous fish in European rivers, the common nase (Chondrostoma nasus L.), is able to reduce periphyton biomass in a eutrophic river. We conducted three consecutive in situ experiments at low, intermediate and high densities of nase in the river using standard tiles on the river bottom naturally covered with periphyton that were accessible to fish and tiles that excluded fish foraging with electric exclosures. The biomass of benthic invertebrate grazers was very low relative to nase. We hypothesised that nase would reduce periphyton biomass on accessible tiles and therefore expected higher periphyton biomass on the exclosure tiles, at least at intermediate and high densities of nase in the river. Contrary to our expectation, the impact of fish grazing was low even at high fish density, as judged by the significantly lower chlorophyll $a$ concentration on exclosure tiles even though the ash-free dry mass on accessible and exclosure tiles did not differ. The lower chlorophyll $a$ concentrations on exclosure tiles might be explained by a higher biomass of invertebrate grazers on the exclosure tiles, which would indicate that the effect of invertebrate grazers was stronger than that of herbivorous fish grazers. The high biomass of invertebrate grazers on exclosure tiles likely arose from the exclusion of zoobenthivorous fish, which occur in the river at high densities. The results of our small-scale experiments suggested that cascading top-down effects of zoobenthivorous fish have a higher impact on periphyton biomass than direct effects of herbivorous nase.

\section{Introduction}

44 Benthic grazing in running waters strongly affects periphyton biomass (Feminella \& Hawkins, 1995; Hillebrand, 2009; Holomuzki, Feminella \& Power, 2010). Invertebrates across different taxonomic groups are able to reduce standing crops of stream periphyton (e.g. Gastropoda: 47 Rosemond, Mulholland \& Elwood, 1993; Rosemond, Mulholland \& Brawley, 2000; 48 Ephemeroptera: Hill \& Knight, 1987; Moulton et al., 2004; Trichoptera: Lamberti \& Resh, 1983;

49 Katano et al., 2007), and benthic grazing limits periphyton biomass accrual in nutrient-enriched 
50 rivers (Peterson et al., 1993; Sturt, Jansen \& Harrison, 2011). Herbivorous fish might also affect 51 periphyton accumulation in streams and shallow rivers. Strong top-down effects of herbivorous 52 fish have been found in subtropical (Schneck, Schwarzbold \& Melo, 2013) and tropical streams 53 (Power, Dudley \& Cooper, 1989; Wootton \& Oemke, 1992; Flecker et al., 2002). However, it 54 has been suggested that fish grazing is more important in tropical streams than in temperate 55 streams due to the higher density and species richness of herbivorous fish in the tropics (Wootton \& Oemke, 1992). Nevertheless, field experiments have shown that the highly abundant small herbivorous cyprinid Campostoma anomalum reduces periphyton biomass in North American streams (Power, Matthews \& Stewart, 1985; Stewart, 1987; Gelwick \& Matthews, 1992). In mesocosms simulating small headwater prairie streams, the presence of one or two herbivorous fish species (Chrosomus erythrogaster, C. anomalum) results in a reduction of algal filament lengths and periphyton biomass (Martin et al., 2016).

In the light of the potentially high top-down impact of grazers in streams and rivers, the question arises whether enhancement of benthic grazing could be used as a tool for the mitigation of eutrophication effects in stream conservation approaches, similar to biomanipulation in lakes (Shapiro \& Wright, 1984; Hansson et al., 1998). In streams and shallow rivers, nutrient enrichment promotes excessive growth of periphyton, which in turn can cause high diurnal fluctuations of oxygen and pH (Dodds \& Welch, 2000; Hilton et al., 2006) and biological clogging of the hyporheic zone (Ibisch, Seydell \& Borchardt, 2009). This reduces the habitat quality for fish and invertebrates (Welch, Quinn \& Hickey, 1992; Hübner, Borchardt \& Fischer, 2009).

However, although the effects of invertebrate grazers on stream periphyton are generally strong (Hillebrand, 2009), they do not seem to be sufficient to prevent algal blooms owing to a temporal mismatch of algal and invertebrate generation times (Rosemond, Mulholland \& Brawley, 2000; Winkelmann et al., 2014). This mismatch has the highest effect in small streams in forested catchments, when canopy cover strongly limits periphyton growth during the vegetation season and therefore algal blooms occur usually only in spring prior to tree foliation (Rosemond, Mulholland \& Brawley, 2000; Winkelmann et al., 2014). In rivers, however, a full canopy cover is rarely reached; therefore, periphyton are not greatly light limited during the vegetation season. Hence, the seasonal offset of algal production and grazing pressure observed in narrow streams might be not as strong in wider rivers. Furthermore, rivers also accommodate larger and often 
81 more diverse fish communities, including herbivorous or facultative herbivorous fish (Oberdorff, 82 Guilbert \& Lucchetta, 1993). Consequently, in shallow rivers, a top-down control of periphyton 83 might be facilitated by the promotion of fish grazing, possibly in combination with the 84 enhancement of invertebrate grazing.

85 In European rivers, the large cyprinid common nase (Chondrostoma nasus L.) is the only 86 obligate herbivorous fish species (Vater, 1997). It feeds exclusively on periphyton, and preferentially on benthic diatoms (Freyhof, 1995; Corse et al., 2010). Despite large-scale population declines, nase is still abundant in many European rivers (Reckendorfer et al., 2001; Melcher, Lautsch \& Schmutz, 2012). The home ranges of nase are well defined, with an average daily activity range of $120 \mathrm{~m}$ (Huber \& Kirchhofer, 1998); therefore, a continuous impact of nase on periphyton in these home ranges might be expected. However, to our knowledge, the quantitative impact of herbivorous nase on periphyton biomass has not yet been investigated. Therefore, our study aimed at assessing whether nase is able to reduce periphyton biomass in a eutrophic river. In three in situ experiments using standardized concrete tiles covered with periphyton and electrical exclusion, we quantified the effects of fish exclusion on periphyton biomass at different densities of nase. We expected that nase, as the only herbivorous fish in the accessible to fish than on exclosure tiles, at least at intermediate and high densities of nase.

\section{Methods}

101 Experimental site

102 Experiments were conducted in the hyporhithral zone of the river Nister (Rhineland-Palatinate, 103 Germany, $50^{\circ} 43^{\prime} \mathrm{N}, 7^{\circ} 44^{\prime} \mathrm{E}$ ), a small gravel-bed river with a drainage area of $246 \mathrm{~km}^{2}$. The 104 average mean discharge is $6.4 \mathrm{~m}^{3} \mathrm{~s}^{-1}$ in winter and $2.4 \mathrm{~m}^{3} \mathrm{~s}^{-1}$ in summer (measured at Heimborn, 105 ID 2724030100; data supplied by State Office for Environment of Rhineland-Palatinate). At the 106 experimental sites, the river is about $10 \mathrm{~m}$ wide and never completely shaded during the 107 vegetation season. The river bed mainly consists of cobbles $(6.3-20 \mathrm{~cm})$ and boulders $(20-63$ $108 \mathrm{~cm}$ ). Land use in the catchment is dominated by forestry, pasture and agriculture. Due to 109 phosphate emissions from several minor municipal wastewater treatment plants and diffuse 110 emissions from agriculture, nutrient levels in the river are high (mean $\pm \mathrm{SD}: 106 \pm 62 \mu \mathrm{g} \mathrm{PO}_{4}-\mathrm{P}$ 
$111 \mathrm{~L}^{-1}, 5.3 \pm 1.2 \mathrm{mg} \mathrm{NO}_{3}-\mathrm{N} \mathrm{L}^{-1} ; \mathrm{n}=18$; monthly measurements between June 2015 and July 2017,

112 except during winter flood). Eutrophication effects, such as oxygen oversaturation and extreme

$113 \mathrm{pH}$, have been observed, especially during spring algal bloom (maximum in April 2016: 182.3\%

$114 \mathrm{O}_{2, \mathrm{pH}}$ 10.2).

115 The benthic algal and cyanobacterial community in the river is largely composed of adnate and 116 loosely attached diatoms. During summer, filamentous cyanobacteria or filamentous green algae,

117 especially Cladophora spp., can become dominant. We conducted the experiments after the

118 spring peak and breakdown of periphyton biomass in early summer.

119 Common nase is the only herbivorous fish in the river. The fish scrape periphyton from coarse 120 substrate, typically swim in shoals and have defined home ranges. Fish grazing pressure in the 121 river can be expected to be highest in run segments with coarse substrate, which are the preferred 122 feeding habitats of nase (Huber \& Kirchhofer, 1998). The invertebrate community is dominated 123 by scraping grazers, especially mayfly larvae (Baetis spp., Ephemerella ignita), chironomid 124 larvae and the snail Ancylus fluviatilis.

125 To quantify effects of fish exclusion, we conducted three consecutive experiments at three 126 different densities of nase (Table 1). The first two experiments were performed in summer 2013 127 at two different sites (sites A and B) representing typical nase feeding habitats (20 m in length) at 128 low (experiment I) and intermediate (experiment II) densities. Site A (low nase density) is 129 located $2.5 \mathrm{~km}$ upstream from site B (intermediate nase density), and nase density was eight 130 times higher at site B than at site A (Table 1). In 2015, stocks of herbivorous nase and the 131 omnivorous European chub (Squalius cephalus L.) were experimentally increased in a $500 \mathrm{~m}$ 132 reach including site $\mathrm{B}$ for a long-term food web manipulation experiment; the experimental reach 133 was defined by fish barriers to avoid fish emigration. In July 2016, we performed a third 134 experiment (experiment III) at site B with a nase density more than 8-fold higher than in 135 experiment II and 70-fold higher than in experiment I (Table 1). At the time of experiment III, 136 nase biomass per area at site B was approximately 100-fold higher than the total benthic 137 invertebrate biomass (nase: $111.5 \mathrm{~g} \mathrm{~m}^{-2}$, total invertebrates: $1.2 \mathrm{~g} \mathrm{~m}^{-2}$ ). Aside from nase, the 138 omnivorous European chub and common dace (Leuciscus leuciscus L.) were the most abundant 139 large fish at the experimental sites (Table 1). The small zoobenthivorous fish species bullhead 140 (Cottus gobio L.), common minnow (Phoxinus phoxinus L.) and stone loach (Barbatula 141 barbatula L.) generally occurred at high abundances at both experimental sites and during all 
142 experiments (Table 1). Fish stocks were assessed by electrofishing campaigns (EFGI 650,

143 Bretschneider Spezialelektronik, Chemnitz, Germany) in June 2013 (site A and B) and July 2016

144 (site B). Electrofishing was approved by the fisheries department of the local environmental 145 agency SGD Nord (Rhineland-Palatinate, Germany). For each experiment, stocks of large fish $146(>15 \mathrm{~cm})$ were estimated in a 500-m reach including the experimental site using the mark147 recapture method. Stocks of small fish $(<15 \mathrm{~cm})$ were estimated in 60-m (experiments I and II) 148 and 40-m (experiment III) long sections close to the experimental site by a three-pass removal 149 method.

Electric exclosures

152 We used low-intensity electric pulses following the principle developed by Pringle \& Blake 153 (1994) to prevent fish but not benthic invertebrates from foraging on standardized concrete tiles $154(40 \mathrm{~cm} \times 40 \mathrm{~cm})$ exposed on the stream bottom. The strength of the electric field determines 155 which organisms are affected by electrical exclusion because the sensitivity to electric fields 156 increases with body size (Moulton et al., 2004). The electric field strength that we used in our 157 experiments was comparable to that used in other field studies in which macroconsumers 158 (approximately $\geq 1 \mathrm{~cm}$, in this case fish and shrimps) were selectively excluded, while smaller 159 invertebrates were not affected by the electric field (Pringle \& Blake, 1994; Pringle \& Hamazaki, 160 1997; Rosemond, Pringle \& Ramirez, 1998). Electrical exclusion has the advantage that it avoids 161 experimental artefacts associated with traditional enclosures or exclosures, such as reduced 162 current velocity, increased sedimentation and shading effects.

163 Two protruding aluminium conductors were attached at opposite sides of each tile and were 164 insulated at the bottom of the tile. Fish exclosure tiles were connected to commercially available 165 electrical fence chargers (experiments I and II: compact B400, Electra Landtechnik GmbH, 166 Vöhl, Germany; experiment III: Voss.farming Aures 3, Elefant-Weidezaungeräte e.K., Ohrstedt, 167 Germany; both approximately $0.3 \mathrm{~J}$ output energy) that emitted approximately 50 electrical 168 pulses per minute and were powered by a 12-V battery. Sets of three exclosures were connected 169 in parallel to a fence charger. Control tiles were constructed in the same manner as exclosures 170 but were not connected to a fence charger. The effectiveness of exclusion was tested in two 171 preliminary experiments with five individuals of nase in artificial indoor-stream channels $(2.6 \mathrm{~m}$ 
$172 \times 0.9 \mathrm{~m} \times 0.5 \mathrm{~m})$ at the University of Koblenz-Landau, Koblenz. In both 24-h experiments,

173 electric pulses effectively prevented fish from foraging on electrified tiles but did not

174 significantly unsettle the animals (see Article S1). This is consistent with observations that we

175 made during the field experiments.

176

\section{Experimental setup and sampling}

178 Experiments I (June 2013) and II (July 2013) ran 18 days, and experiment III (July 2016) ran 19

179 days. Each separate experiment had a total of 18 tiles; half the tiles were electrified to exclude

180 fish, and the other half were non-electrified to allow fish access. Electrified and non-electrified

181 tiles were placed at least $2 \mathrm{~m}$ apart from each other to avoid an electric field between exclosures

182 and controls. To allow initial periphyton growth, tiles were exposed on the river bottom two

183 weeks prior to the start of experiments. On at least three occasions during the experiments, we

184 measured water depth (only in experiments I and II), photosynthetically active radiation (PAR)

185 using a LI-250 light meter (LI-COR, Lincoln, Nebraska) with a spherical micro-quantum sensor

186 (US-SWS/L, Heinz Walz GmbH, Effeltrich, Germany) and current velocity using a flow meter

187 with a vane wheel flow sensor (HFA hand-held unit with FA sensor, Hoentzsch GmbH,

188 Waiblingen, Germany) above each tile.

189 At the end of each experiment, we sampled periphyton and benthic invertebrates to control for 190 possible effects of invertebrate grazing. Fence chargers were not turned off until immediately

191 before sampling to ensure continuous fish exclusion. Periphyton and benthic invertebrate 192 samples were each taken from half of the area of each tile. First, half of the tile was covered with 193 a metal frame $(20 \mathrm{~cm} \times 40 \mathrm{~cm})$ to protect the area for periphyton sampling. Invertebrates were 194 sampled from the uncovered area by scraping with a coarse brush. Animals and organic material 195 were washed into a net (500- $\mu \mathrm{m}$ mesh), which was positioned at the downstream edge of the tile.

196 Subsequently, the invertebrate samples were rinsed over a $500-\mu \mathrm{m}$ sieve and stored in $70 \%$

197 ethanol. The tile was then carefully removed from the river bottom, and periphyton was removed

198 from the other half of the tile by brushing the area carefully with a coarse brush and up to 500

$199 \mathrm{~mL}$ river water. The resulting periphyton suspensions were transported in the dark to the 200 laboratory. 
201 In experiment III, additional periphyton and benthic invertebrate samples were taken

202 approximately $10 \mathrm{~m}$ downstream of the experimental site to compare the colonization of tiles and

203 natural substrates in the river. These samples were actually collected for another field study, and

204 periphyton were sampled five days before the end of experiment III and invertebrates were

205 sampled one day after the end of experiment III. Ten stones were randomly chosen over the

206 entire width of the river in order to obtain one mixed sample; periphyton was removed by

207 carefully brushing the stone surface with a coarse brush and river water. Benthic invertebrates

208 were sampled with three Surber samplers (total area $0.24 \mathrm{~m}^{2}, 500-\mu \mathrm{m}$ mesh).

209 Laboratory analyses

210 Nutrient concentrations were measured photometrically (nitrate: DIN EN ISO 13395, 1996;

211 phosphate: DIN EN ISO 15681-2, 2005) using a continuous flow analyser (CFA, AutoAnalyser

212 3; Seal Analytical GmbH, Norderstedt). Total periphyton biomass was estimated as ash-free dry

213 mass (mg AFDM cm$~^{-2}$ ), and autotrophic periphyton biomass was estimated as chlorophyll $a$

214 concentration ( $\mu \mathrm{g} \mathrm{Chl} a \mathrm{~cm}^{-2}$ ). Periphyton biomass was quantified considering the total volume

215 of the obtained periphyton suspension and the sampled area of tiles (experiments I-III) and

216 stones (additional samples in experiment III). The surface area of stones sampled close to the

217 experimental site were determined by carefully wrapping the stone in aluminium foil;

218 overlapping areas were cut off, and the foil was weighed. The total volume of each periphyton

219 suspension was determined, and the suspension was then homogenized using a magnetic stirrer

220 to ensure comparable aliquots. For quantification of AFDM, $10 \mathrm{~mL}$ aliquots were transferred to

221 pre-weighed ceramic crucibles and dried at $60{ }^{\circ} \mathrm{C}$ for $24 \mathrm{~h}$. Dried samples were weighed, ashed

222 at $510{ }^{\circ} \mathrm{C}$ for $5 \mathrm{~h}$ in a muffle furnace and subsequently reweighed.

223 To determine Chl $a$ concentrations, triplicate aliquots were centrifuged at 13,000 rpm for $3 \mathrm{~min}$ 224 (16,060 $\times g$, Micro 200R; Hettich Zentrifugen, Tuttlingen). The aliquot volume was $2 \mathrm{~mL}$ in 225 experiments I and II but $0.5 \mathrm{~mL}$ in experiment III because the periphyton suspensions were 226 thicker. The supernatants were discarded, and pellets were stored at $-80^{\circ} \mathrm{C}$. Chl $a$ was extracted 227 and spectrophotometrically analysed according to Mewes, Spielvogel \& Winkelmann (2017). In 228 short, pellets were homogenized in $500 \mu \mathrm{L}$ of $96 \%$ ethanol buffered with $1 \mathrm{~g} \mathrm{MgCO}_{3} \mathrm{~L}^{-1}$ using a 229 disperser (Ultra Turrax T8, IKA, Staufen, Germany), except for samples in experiment III, which 230 were homogenized in a mixing mill (MM 400, Retsch Technology GmbH, Haan, Germany). 
231 Another $0.5,1.0$ or $1.5 \mathrm{~mL}$ of buffered $96 \%$ ethanol was added, depending on the intensity of 232 green colouration, to prevent incomplete extraction in high-quantity samples. Chl $a$ was 233 extracted for at least $3 \mathrm{~h}$ at room temperature in the dark. Subsequently, the samples were 234 centrifuged at 6,000 rpm $(3,421 \times g$, Micro 200R) for $3 \mathrm{~min}$, and Chl $a$ in the supernatant was 235 measured spectrophotometrically (Specord 205; Analytic Jena, Jena, Germany) at $665 \mathrm{~nm}$ and 236 corrected for turbidity at $750 \mathrm{~nm}$. If the sample absorbance exceeded 1, the sample was 237 appropriately diluted with buffered ethanol to give a reading of less than 1.

238 In experiment III, additional $2 \mathrm{~mL}$ aliquots were taken from the homogenized periphyton 239 suspensions and stored at $-80^{\circ} \mathrm{C}$ for later analysis of the benthic algal and cyanobacterial 240 community composition. The mean percentage of each taxonomic group (diatoms, green algae 241 and cyanobacteria) in the suspension was estimated microscopically (400× magnification) 242 relative to the total area covered by algae and cyanobacteria on the slide (which was set to $100 \%$ 243 in each microscopic field of view). The mean percentage of each group was estimated from 50 244 fields of view per slide, and three slides were analysed per sample.

245 All individuals from each benthic macroinvertebrate sample were sorted under a dissecting 246 microscope, identified to the lowest practicable taxonomic level and counted. For each taxon in 247 each sample, at least 50 individuals were measured to the nearest $0.1 \mathrm{~mm}$. If less than 50 248 individuals occurred for one taxon per sample, all individuals of the sample were measured. The 249 individual body mass (dry mass) was calculated using length-weight regressions. For all taxa 250 except Chironomidae, we used regression models from the literature (Meyer, 1989; Benke et al., 251 1999; Baumgärtner \& Rothhaupt, 2003; Edwards et al., 2009). For Chironomidae, we used data 252 from our own samples to obtain a power function relating body length (BL) and dry mass (DM): $253 \mathrm{DM}=0.0013 * \mathrm{BL}^{2.8024}\left(\mathrm{r}^{2}=0.96, \mathrm{n}=62\right)$. We did this because Chironomidae were the dominant 254 group in most of our samples, they consist of species different than those in samples reported in 255 literature, and published regressions for Chironomidae are based on a relatively small sample 256 size (e.g. 16 samples in Meyer, 1989). The samples used to determine the body length and dry 257 mass of chironomid larvae were taken from the river Nister and had been stored in 70\% ethanol 258 for 6 months. The length of undamaged individuals was measured to the nearest $0.1 \mathrm{~mm}$. 259 Afterwards, each individual was transferred to a pre-weighed reaction tube and dried for $24 \mathrm{~h}$ at $26060{ }^{\circ} \mathrm{C}$. After cooling in a desiccator, dry mass was determined to the nearest $0.01 \mathrm{mg}$ using a 261 microbalance (XS205 Dual Range, Mettler-Toledo, Columbus, Ohio, USA). To reduce 
262 measurement error, the dry mass of smaller specimens $(<5 \mathrm{~mm})$ was determined by weighing $2-$

26315 individuals of a similar length together and calculating a mean individual body mass. To 264 correct the individual dry mass for mass loss owing to preservation, we used a conversion factor 265 of 1.26 (Mährlein et al., 2016).

266

267 Data analysis

268 Stocks of large fish $(>15 \mathrm{~cm})$ were calculated using Chapman's modified Petersen estimator 269 (Ricker, 1975). Stocks of small fish $(<15 \mathrm{~cm})$ were calculated using the De Lury $(1951)$ 270 regression method. In the case of non-significant regression coefficients $\left(\mathrm{R}^{2}<0.88\right)$, only the 271 total number of caught individuals per $\mathrm{m}^{2}$ is given because it represents a minimum estimation 272 for the population density of small fish. Chl $a$ concentration was calculated per area of the tile 273 surface (as in Mewes, Spielvogel \& Winkelmann, 2017). Means of periphyton biomass (Chl $a$ 274 and AFDM) on exclosure and accessible tiles were compared using independent $t$-tests.

275 We assessed differences in the invertebrate community composition between exclosure and 276 accessible tiles using analysis of similarities (ANOSIM) based on benthic invertebrate biomass. 277 If ANOSIM results were significant, a similarity percentage (SIMPER) analysis was used to 278 identify the taxa that were mainly responsible for the differences between exclosure and 279 accessible tiles. In experiments I and III, nine exclosure and nine accessible tiles were analysed; 280 in experiment II, only eight tiles of each type were analysed due to desiccation of one sample. To 281 calculate the total biomass of invertebrate grazers in each sample, we weighted the biomass of 282 each herbivorous and omnivorous species according to the average proportion of plant food in 283 their diet (Schmedje \& Colling, 1996). The mean total grazer biomass of benthic invertebrates 284 and the mean biomass of several dominant grazer taxa on exclosure and accessible tiles were 285 compared using $t$-tests and adjusted for multiple comparisons using the Bonferroni-Holm 286 correction.

287 To check whether environmental factors distorted the effects of fish exclusion on periphyton 288 biomass, we used $t$-tests of differences in mean water depth, PAR and current velocity (averaged 289 over the experimental period for each tile) between exclosure and accessible tiles. In addition, 290 Pearson correlations were calculated to assess any influence of environmental factors on

291 periphyton and grazer biomass. Non-normally distributed data were log-transformed for 
292 Pearson's correlation analysis. For all comparisons of means, Welch's test was used instead of

293 the $t$-test when the assumption of homogeneity of variance was not met. Statistical analyses were 294 performed and graphs were plotted using R version 3.3.3 (R Development Core Team, 2016).

295

296

297

298

299

300

301

302

303

304

305

306

307

308

309

310

311

312

313

314

315

316

317

318

319

320

321

\section{Results}

When fish were excluded from the tiles, autotrophic periphyton biomass decreased, as shown by the significantly lower $\mathrm{Chl} a$ levels on tiles inaccessible to fish (exclosure) than on the tiles to which fish had access (control) at intermediate (experiment II) and high (experiment III) densities of nase (II: $p<0.01$; III: $p=0.02 ; \mathrm{n}=9$; $t$-test; Fig. 1B and C). At a low nase density (experiment I), $\mathrm{Chl} a$ concentrations on the fish exclosure tiles were not significantly lower (Chl $a: p=0.06, \mathrm{n}=9, t$-test, Fig. 1A). By contrast, total periphyton biomass measured as AFDM did not differ between accessible and exclosure tiles (I: $p=0.33$, Welch test; II: $p=0.19, t$-test; III: $p$ $=0.93$, Welch test; $\mathrm{n}=9$, Fig. $2 \mathrm{~A}-\mathrm{C}$ ). At a high nase density (experiment III), the variance of AFDM was significantly higher on the exclosure tiles than on the accessible tiles $(p<0.01, \mathrm{n}=$ 9, F-test, Fig. 2C). Overall, both the Chl $a$ concentration and AFDM were lowest on both sets of tiles at a low nase density and highest at a high nase density.

The algal and cyanobacterial communities on the tiles at a high nase density were dominated by diatoms (mean $\pm \mathrm{SD}, \mathrm{n}=9$ : exclosures: $63 \% \pm 9 \%$, controls: $59 \% \pm 6 \%$ ), followed by green algae (exclosures: $33 \% \pm 9 \%$, controls: $27 \% \pm 8 \%$ ) and cyanobacteria (exclosures: $3 \% \pm 4 \%$, controls: $14 \% \pm 10 \%)$. Green algae were mostly filamentous, and included the taxa Cladophora spp. and Microspora spp. Benthic diatoms included loosely attached taxa such as Navicula spp., and stalked taxa such as Gomphonema spp., which were often found epiphytic on Cladophora spp. Cyanobacteria included mostly filamentous taxa, especially Phormidium spp. and bundles of Homoeothrix spp. The estimated proportion of cyanobacteria was higher on the accessible control tiles than on the exclosure tiles ( $\mathrm{p}<0.01, \mathrm{n}=9$, $\mathrm{t}$-test), which might point to effects of grazing on the periphyton community structure. On natural river stones, the algal and cyanobacterial communities differed from those on the tiles (mixed sample obtained from ten stones: $60 \%$ filamentous cyanobacteria, $38 \%$ diatoms, $2 \%$ filamentous green algae). The difference between tiles and natural substrates might have been even more intense owing to the time delay between samplings especially because there was a sunny period between the sampling 
322 dates. However, the communities on natural river stones and on the tiles generally consisted of

323 similar taxa (e.g. Homoeothrix spp., Phormidium spp., Navicula spp., Gomphonema spp.,

324 Microspora spp.). Periphyton biomass on the river stones was in the same order of magnitude as

325 on the accessible tiles (mixed sample obtained from ten stones: $23.7 \mu \mathrm{g} \mathrm{cm}^{-2} \mathrm{Chl} a, 2.4 \mathrm{mg} \mathrm{cm}^{-2}$

326 AFDM; accessible tiles of experiment III [mean $\pm \mathrm{SD}, \mathrm{n}=9$ ]: $30.0 \pm 6.5 \mu \mathrm{g} \mathrm{cm}^{-2} \mathrm{Chl} a, 3.1 \pm$

$3270.5 \mathrm{mg} \mathrm{cm}^{-2}$ AFDM).

328 The composition of the benthic invertebrate community differed between exclosure and 329 accessible tiles at high and intermediate nase densities, but not at a low nase density (I: $R=0.08$, $330 p=0.13$; II: $\mathrm{R}=0.18, p=0.03$; III: $\mathrm{R}=0.64, p=0.001$, ANOSIM). At a high nase density

331 (experiment III), Chironomidae and Baetis spp. contributed most to the dissimilarity between 332 exclosure and accessible tiles (34\% and 28\%, respectively; SIMPER). At an intermediate nase 333 density (experiment II), Chironomidae and Ephemerella ignita contributed most to the 334 dissimilarity between exclosure and accessible tiles (31\% and 18\%, respectively, SIMPER). The 335 biomasses of the taxa responsible for the differences in SIMPER were consistently higher on the 336 fish exclosure tiles. In all three experiments, Chironomidae and mayfly grazers (Baetis spp., 337 Ephemerella ignita and occasionally Ecdyonurus spp.) contributed most to grazer biomass.

338 Grazer biomass was affected by the presence of fish. At a high nase density (experiment III), 339 total grazer biomass and biomass of mayfly grazers were significantly higher on the fish 340 exclosure tiles than on the accessible control tiles (total: $p<0.001$, mayfly: $p=0.001$; 341 chironomid: $p=0.16, \mathrm{n}=9$; Welch test; Fig. $3 \mathrm{C}$ ). At an intermediate nase density, at least the

342 Chironomidae biomass showed a tendency to increase (II: total: $p=0.16$, mayfly: $p=0.16$, 343 chironomid: $p=0.051 ; \mathrm{n}=8$; Welch test; Fig. 3B). At a low nase density, grazer biomass did not 344 differ between exclosure and accessible tiles (I: total: $p=0.30$, mayfly: $p=0.24$, chironomid: $p=$ $3450.36 ; \mathrm{n}=9 ; t$-test, Fig. $3 \mathrm{~A}$ ), and grazer biomass was overall lowest in this experiment.

346 Invertebrate colonization of the tiles was comparable but not identical to that of the natural 347 substrates close to the experimental site in experiment III. Some taxa, such as Ancylus fluviatilis 348 and Elmis sp., occurred more often on natural substrates. However, Chironomidae, Baetis spp. 349 and Ephemerella ignita were among the most important invertebrate grazers $(45 \%$ of grazer 350 biomass) in the river, and had densities comparable to those on the tiles (see Table S2). 
351 There was no evidence that the environmental factors water depth, light and current velocity

352 affected the experimental results. The water depths at exclusion and control tile sites were

353 similar (I: $p=0.82$; II: $p=0.75$; III not measured; $t$-test; $\mathrm{n}=9$; Table 2). The light supply was

354 also similar at exclusion and control tile sites in all three experiments (I: $p=0.72$, Welch test; II:

$355 p=0.64, t$-test; III: 0.45, Welch test; $\mathrm{n}=9$, Table 2). Current velocities were similar at exclusion

356 and control tile sites in experiments I and II (I: $p=0.88, \mathrm{II}: p=0.63, \mathrm{n}=9$, $t$-test) but was

357 significantly higher around the fish exclosure tiles than around the control tiles in experiment III

$358(p=0.03, \mathrm{n}=9, t$-test, Table 2). However, although some significant correlations were found

359 between environmental factors and biotic response variables in experiments I and II (Table 3),

360 there was no significant relationship between current velocity and Chl $a$ (exclosures: $p=0.45$;

361 controls: $p=0.18 ; \mathrm{n}=9$ ), AFDM (exclosures: $p=0.47$; controls: $p=0.22 ; \mathrm{n}=9$ ) or between

362 current velocity and grazer biomass (exclosures: $p=0.65$; controls: $p=0.15 ; \mathrm{n}=9$; Table 3 ) in

363 experiment III, where current velocity differed between exclusion and control tile sites.

364

365 Discussion

366 As grazers are able to strongly control periphyton biomass (Feminella \& Hawkins, 1995; 367 Hillebrand, 2009) and eutrophication-driven algal blooms detrimentally affect the ecological 368 quality of running waters (Dodds \& Welch, 2000; Biggs, 2000; Hilton et al., 2006), the active 369 promotion of benthic grazing might be a future tool for improving the quality of shallow rivers or unshaded streams. However, in contrast to the known top-down effects of benthic invertebrate grazers, there is a considerable gap of knowledge concerning the top-down effects of herbivorous

372 fish. To assess whether top-down effects of herbivorous fish are able to control periphyton

373 biomass, we conducted in situ exclosure experiments in which fish were not allowed to gain 374 access to tiles colonized by periphyton and compared the results to those obtained with 375 accessible control tiles. The unspecific exclusion of fish in our study was expected to be 376 sufficient to reduce grazing intensity, because the common nase (C. nasus) is a specialized 377 periphyton feeder (Freyhof, 1995; Corse et al., 2010) and the only herbivorous fish in the river.

378 We expected strong top-down effects by nase on periphyton biomass, especially because we 379 frequently observed visible traces of feeding of nase in the river during summer. Therefore we 380 hypothesized that nase can reduce periphyton biomass, which in our experiments would result in 
381 higher periphyton biomass on exclosure tiles compared to accessible tiles in a eutrophic river

382 with intermediate and high densities of nase.

383 In contrast to our hypothesis, autotrophic periphyton biomass (measured as $\mathrm{Chl} a$ ) was lower on 384 the exclosure tiles at intermediate and high densities of nase. This possibly indicates a low 385 impact of fish grazing at this experimental scale. This result was surprising because it had been 386 observed in other small-scale experiments that herbivorous fish exert strong top-down effects on 387 periphyton (e.g. Wootton \& Oemke, 1992; Flecker et al., 2002; Schneck, Schwarzbold \& Melo, 388 2013; Martin et al., 2016), and it was even shown that the small cyprinid species central 389 stoneroller (C. anomalum) reduces periphyton on the mesohabitat scale (Power, Matthews \& 390 Stewart, 1985; Stewart, 1987; Gelwick \& Matthews, 1992).

391 A possible explanation for the lower autotrophic periphyton biomass observed on fish exclosure 392 tiles might be a strong indirect top-down effect of zoobenthivorous fish at the experimental site.

393 This is unexpected because we assumed that direct top-down control by nase would be stronger 394 than indirect top-down control over two trophic levels, especially as the biomass of nase was 395 more than 100-fold higher than that of invertebrates at the experimental site. Unfortunately, there 396 is uncertainty whether zoobenthivorous fish were completely excluded by the electrical fences on 397 the tiles because we did not test the effectiveness of the electrical exclusion for small fish. 398 However, other studies that used electrical exclosures at a similar intensity reported the exclusion 399 of animals $\geq 1 \mathrm{~cm}$ (Pringle \& Blake, 1994; Pringle \& Hamazaki, 1997; Rosemond, Pringle \& 400 Ramirez, 1998), which would have excluded all zoobenthivorous fish in our experiments. In 401 addition, our results strongly indicate that benthic invertebrates might have been released from 402 predation pressure, thereby increasing invertebrate grazing. This assumption is supported by our 403 observation of a higher invertebrate grazer biomass in general and mayfly grazers in particular 404 on exclosure tiles than on control tiles. If indeed invertebrate grazing was responsible for the 405 observed results, then the indirect control of periphyton biomass by zoobenthivorous fish via 406 invertebrate grazers was stronger than the direct top-down effect of herbivorous nase in our 407 small-scale experiments.

408 In principle, the occurrence of a trophic cascade from fish over invertebrate grazers on 409 periphyton seems likely because comparable effects have been observed under near-natural 410 conditions in stream ecosystems for both zoobenthivorous fish (Winkelmann et al., 2014) and 
411 drift-feeding fish (Huryn, 1998; Buria et al., 2010; Pagnucco, Remmal \& Ricciardi, 2016) and in 412 many small-scale experiments (e.g. Power, 1990b; Flecker \& Townsend, 1994; Dahl, 1998; 413 Kurle \& Cardinale, 2011). Moreover, effects of zoobenthivorous fish on the composition of the 414 benthic invertebrate community have been observed on different experimental scales (large 415 scale: Winkelmann et al., 2007, 2011; Worischka et al., 2014; small scale: Dahl, 1998; Shelton et 416 al., 2016). Grazing mayfly larvae and chironomids are important prey species for 417 zoobenthivorous fish (Copp, Spathari \& Turmel, 2005; Ureche et al., 2010; Worischka et al., 418 2015), which is in agreement with the strongest effects of fish exclusion on mayflies and 419 chironomids in our experiments.

420 However, the strength of the observed effects did not correspond to the density of small 421 zoobenthivorous fish (catch per $\mathrm{m}^{2}$ ). Based only on the total density, the strongest effects would 422 have been expected in experiment I with the highest density of zoobenthivorous fish (low nase 423 density). However, our results showed the strongest effect in experiment III (significant decrease 424 in Chl $a$ concentrations and significant increase in benthic grazers), in which the total density of 425 zoobenthivorous fish was lowest. One explanation for these results is that the strength of the 426 predation pressure on the tiles might have been affected by a species shift within the 427 zoobenthivorous fish community, owing to differences in their foraging behaviour. Stone loach 428 (B. barbatula), whose stock was highest at high nase densities (experiment III), feeds in habitats 429 with higher current velocities than other zoobenthivorous fish species (Worischka et al., 2012) 430 and can therefore be expected to feed frequently on the experimental tiles. Another explanation 431 for these results is that the strong effects are due to the relatively high density of the large 432 omnivorous fish European chub (S. cephalus) and dace (L. leuciscus). Both species feed to a 433 considerable proportion on benthic prey (Vlach, Švátora \& Dušek, 2013) and might therefore 434 have reduced benthic grazers on the tiles accessible to fish.

435 While the explanations stated above focused on top-down regulation, the higher Chl $a$ 436 concentration on accessible control tiles might also be the result of a stimulation of periphyton 437 growth due to fish grazing, which represents an overcompensation of top-down regulation. 438 During the first two weeks of experiment III, we frequently observed nase foraging on the 439 control tiles and found highly visible traces of feeding. Such newly grazed patches, free from 440 senescent algae and detritus, offer optimal growth conditions for new algae (Lamberti \& Resh, 441 1983; McCormick \& Stevenson, 1989), thus yielding comparatively more Chl $a$. This 
442 explanation is supported by the observation that while autotrophic biomass was significantly 443 higher in the controls in experiments II and III, total biomass (AFDM), including heterotrophs 444 and detritus other than living algae, was similar in all experiments. The presence of herbivorous 445 fish on the accessible tiles might have caused increased removal of detritus (Power, 1990a; 446 Flecker, 1996), allowing algae to increase their growth rate, thereby overcompensating fish 447 grazing. The significantly lower variance of AFDM in the controls at high nase density 448 (experiment III) could indicate that grazing by nase had a homogenizing effect on the spatial 449 scale of the experimental site, leading to more similar total periphyton biomass in the controls, 450 thereby supporting the second explanation.

451 Several methodical issues possibly led to an increase in variability and a lower observed effect of 452 fish. First, annual and seasonal differences in the abundance and developmental stages of benthic 453 invertebrates between the experiments cannot be ruled out completely. Unfortunately, we were 454 not able to run the experiments in parallel and had to use a consecutive experimental design. An 455 underestimation of indirect effects of zoobenthivorous fish might have resulted from the 456 conservative estimation of the total grazer biomass. Especially for calculating the grazer biomass 457 of Chironomidae, we used a small average proportion of plant food in their diet (20\%; Schmedtje 458 \& Colling, 1996). Nevertheless, Chironomidae larvae are a diverse group that vary greatly in 459 their feeding habits. Several taxa feed predominantly on algae (Cummins, 1973; Pinder, 1992; 460 Tarkowska-Kukuryk, 2013) and are able to exert strong top-down effects on periphyton (Power, 461 1990b; Tarkowska-Kukuryk, 2013). Assuming that mostly grazing chironomids settled on the 462 tiles, it seems likely that grazing by chironomid larvae caused the lower Chl $a$ concentration on 463 the exclosure tiles in experiment II even though chironomid biomass did not significantly 464 increase.

465 In addition, we suspect that especially in experiment I, bottom-up effects were likely more 466 important than top-down effects because light intensity was highest and periphyton biomass was 467 lowest for accessible and exclosure tiles of this experiment, while invertebrate grazer biomass 468 was low. Higher light availability could have promoted fast periphyton growth, which leads to 469 self-shading and ultimately to detachment of periphyton and thereby masks potential effects of 470 fish exclusion (Higgins, Hecky \& Guildford, 2008). 
471 The use of artificial substrates, which might result in a different community structure of 472 periphyton and invertebrates owing to uniform surface texture, size and colonization time 473 (Cattaneo \& Amireault, 1992), means our experimental results cannot be directly transferred to 474 the situation in a real ecosystem. However, the relatively high proportion of filamentous green 475 algae and cyanobacteria, especially the occurrence of attached taxa such as Cladophora spp., 476 shows that the concrete tiles were a reasonably good facsimile and that colonization time was 477 long enough to allow the development of mid- to late-successional stages of periphyton. 478 Therefore, we think that although the periphyton assemblage on the tiles was not identical to that 479 of natural substrates, it sufficiently represents the natural colonization of the river bed during 480 summer.

481 Furthermore, the exact fish densities at the experimental site (20 $\mathrm{m}$ in length) were not known 482 because fish moved within their natural home range. This uncertainty might have been overcome 483 by using an enclosure design. However, such a design seems undesirable because it would have 484 affected both abiotic conditions and fish behaviour. Because of the different habitat use of 485 zoobenthivorous fish and nase, we chose different spatial scales for fish stock estimations. 486 Zoobenthivorous fish are mostly stationary and small; we estimated their density in 60-m 487 sections very close to the experimental sites. Nase, on the other hand, usually swim in shoals that 488 move actively within defined home ranges (Huber \& Kirchhofer, 1998). Therefore, we found it 489 necessary to estimate nase stocks on a large scale $(500 \mathrm{~m})$ to reflect the potential grazing impact

490 of nase at the experimental sites. Although we cannot rule out that nase changed their feeding 491 places from time to time over the experimental periods, we expect that within the experimental 492 period of more than two weeks, differences in day-to-day feeding areas were reasonably 493 integrated over time.

494 Finally, the small spatial and temporal scale of our experiments does not allow us to draw a 495 general conclusion from our experimental results on the possible top-down control of periphyton 496 by nase in eutrophic rivers. Especially the effect of invertebrate grazing seems likely to be 497 particularly strong on a small spatial scale but less relevant at larger scales (Englund, 1997; Gil, 498 Jiao \& Osenberg, 2016). 


\section{Conclusions}

501 Our results indicate that the active promotion of benthic grazing might be a possible tool to 502 reduce eutrophication effects in rivers, but also highlight the complexity of top-down control in 503 river food webs. In our small-scale experiments, cascading effects of zoobenthivorous fish via 504 invertebrate grazers might have been stronger than direct top-down effects of herbivorous nase. 505 However, we cannot determine whether fish grazing or invertebrate grazing is more important on

506 the ecosystem scale because the potential impact of herbivorous nase remained unclear, likely 507 owing to the unspecific exclusion of fish in our experiment. To assess the top-down effects of 508 herbivorous nase in eutrophic rivers, large-scale and long-term experiments that consider the 509 impact of spatial and seasonal variability are needed.

510

\section{Acknowledgements}

512 We thank Christian Sodemann and Manfred Fetthauer for technical advice and for valuable 513 support during field work. We also thank all colleagues, students and volunteers of the local river 514 protection association ARGE/Nister e.V. who helped with the electrofishing and field sampling.

515 We are also grateful to Karen Brune for linguistic support. Furthermore, we thank the reviewers 516 Mary Power and Kiran Liversage and the academic editor Richard Taylor for their thoughtful 517 comments and suggestions, which greatly improved the manuscript.

\section{References}

520 Baumgärtner D, Rothhaupt KO. 2003. Predictive length-dry mass regressions for freshwater invertebrates in a pre-alpine lake littoral. International Review of Hydrobiology 88:453463. DOI: 10.1002/iroh.200310632.

523 Benke AC., Huryn AD., Smock LA., Wallace JB. 1999. Length-mass relationships for freshwater macroinvertebrates in North America with particular reference to the Southeastern United States. Journal of the North American Benthological Society 18:308-343. DOI: $10.2307 / 1468447$. 
527 Biggs BJF. 2000. Eutrophication of streams and rivers: dissolved nutrient-chlorophyll

528 relationships for benthic algae. Journal of the North American Benthological Society

$529 \quad 19: 17-31$. DOI: $10.2307 / 1468279$.

530 Buria L, Albariño R, Villanueva VD, Modenutti B, Balseiro E. 2010. Does predation by the introduced rainbow trout cascade down to detritus and algae in a forested small stream in Patagonia? Hydrobiologia 651:161-172. DOI: 10.1007/s10750-010-0293-9.

533 Cattaneo A, Amireault MC. 1992. How artificial are artificial substrata for periphyton? Journal of the North American Benthological Society 11:244-256. DOI: 10.2307/1467389.

Copp GH, Spathari S, Turmel M. 2005. Consistency of diel behaviour and interactions of stream fishes and invertebrates during summer. River Research and Applications 21:75-90.

Corse E, Costedoat C, Chappaz R, Pech N Martin JF, Gilles A. 2010. A PCR-based method for diet analysis in freshwater organisms using 18S rDNA barcoding on faeces. Molecular Ecology Resources 10:96-108. DOI: 10.1111/j.1755-0998.2009.02795.x.

541 Cummins, KW. 1973. Trophic relations of aquatic insects. Annual Review of Entomology 18:183-206. DOI: 10.1146/annurev.en.18.010173.001151.

Dahl J. 1998. Effects of a benthivorous and a drift-feeding fish on a benthic stream assemblage. Oecologia 116:426-432. DOI: 10.1007/s004420050606.

De Lury DB. 1951. On the planning of experiments for the estimation of fish populations. Journal of the Fisheries Research Board of Canada 8:281-307.

547 DIN EN ISO 13395. 1996. Water quality - determination of nitrite nitrogen and nitrate nitrogen and the sum of both by flow analysis (CFA and FIA) and spectrometric detection. 
549 DIN EN ISO 15681-2. 2005. Water quality - Determination of orthophosphate and total 550 phosphorus contents by flow analysis (FIA and CFA) - Part 2: Method by continuous $551 \quad$ flow analysis (CFA).

552 Dodds WK, Welch EB. 2000. Establishing nutrient criteria in streams. Journal of the North 553 American Benthological Society 19:186-196.

554 Edwards FKL, Armand L, Vincent HM, Jones IJ. 2009. The relationship between length, mass 555 and preservation time for three species of freshwater leeches (Hirudinea). Fundamental and Applied Limnology 173: 321-327. DOI: 10.1127/1863-9135/2009/0173-0321.

Englund G. 1997. Importance of spatial scale and prey movements in predator caging experiments. Ecology 78:2316-2325. DOI: 10.2307/2265894.

Feminella JW, Hawkins CP. 1995. Interactions between stream herbivores and periphyton: A quantitative analysis of past experiments. Journal of the North American Benthological Society 14:465-509. DOI: 10.2307/1467536.

Flecker AS. 1996. Ecosystem engineering by a dominant detritivore in a diverse tropical stream. Ecology 77:1845-1854. DOI: 10.2307/2265788.

Flecker AS, Taylor BW, Bernhardt ES, Hood JM, Cornwell WK, Cassatt SR, Vanni MJ, Altman NS. 2002. Interactions between herbivorous fishes and limiting nutrients in a tropical

Flecker AS, Townsend CR. 1994. Community-wide consequences of trout introduction in New Zealand streams. Ecological Applications 4:798-807. DOI: 10.2307/1942009.

DOI:

10.1890/00129658(2002)083[1831:IBHFAL]2.0.CO;2. 
572 Gelwick FP, Matthews WJ. 1992. Effects of an algivorous minnow on temperate stream 573 ecosystem properties. Ecology 73:1630-1645. DOI: 10.2307/1940016.

574 Gil MA, Jiao J, Osenberg CW. 2016. Enrichment scale determines herbivore control of primary 575 producers. Oecologia 180:833-840. DOI: 10.1007/s00442-015-3505-1.

576 Hansson LA, Annadotter H, Bergman E, Hamrin SF, Jeppesen E, Kairesalo T, Luokkanen E,

578

579

580

581

582

583

584

585

586

587

588

589

590

591

592

593

Nilsson PÅ, Søndergaard M, Strand J. 1998. Biomanipulation as an application of foodchain theory: constraints, synthesis, and recommendations for temperate lakes. Ecosystems 1:558-574.

Higgins SN, Hecky RE, Guildford SJ. 2008. The collapse of benthic macroalgal blooms in response to self-shading. Freshwater Biology 53:2557-2572. DOI: 10.1111/j.13652427.2008.02084.x.

Hill WR, Knight AW. 1987. Experimental analysis of the grazing interaction between a mayfly and stream algae. Ecology 68:1955-1965. DOI: 10.2307/1939886.

Hillebrand H. 2009. Meta-analysis of grazer control of periphyton biomass across aquatic ecosystems (1). Journal of Phycology 45:798-806. DOI: 10.1111/j.15298817.2009.00702.x.

Hilton J, O’Hare M, Bowes MJ, Jones JI. 2006. How green is my river? A new paradigm of eutrophication in rivers. Science of The Total Environment 365:66-83. DOI: 10.1016/j.scitotenv.2006.02.055.

Holomuzki JR, Feminella JW, Power ME. 2010. Biotic interactions in freshwater benthic habitats. Journal of the North American Benthological Society 29:220-244. DOI: $10.1899 / 08-044.1$. 
594 Huber M, Kirchhofer A. 1998. Radio telemetry as a tool to study habitat use of nase 595 (Chondrostoma nasus L.) in medium-sized rivers. Hydrobiologia 371-372:309-319. 596 DOI: $10.1023 / \mathrm{A}: 1017005523302$.

597 Hübner D, Borchardt D, Fischer J. 2009. Cascading effects of eutrophication on intragravel life 598 stages of European Grayling (Thymallus thymallus L.). Arch. Hydrobiol. Spec. Issues Advanc. Limnol. 61:205-224.

Huryn AD. 1998. Ecosystem-level evidence for top-down and bottom-up control of production in a grassland stream system. Oecologia 115:173-183. DOI: 10.1007/s004420050505.

Ibisch RB, Seydell I, Borchardt D. 2009. Influence of periphyton biomass dynamics on biological colmation processes in the hyporheic zone of a gravel bed river (River Lahn, 604 Germany). Arch. Hydrobiol. Spec. Issues Advanc. Limnol.:87-104.

Katano I, Doi H, Houki A, Isobe Y, Oishi T. 2007. Changes in periphyton abundance and 606 607 community structure with the dispersal of a caddisfly grazer, Micrasema quadriloba. Limnology 8:219-226. DOI: 10.1007/s10201-007-0211-7.

Kurle CM, Cardinale BJ. 2011. Ecological factors associated with the strength of trophic 609 cascades in streams. Oikos 120:1897-1908. DOI: 10.1111/j.1600-0706.2011.19465.x. of grazing by a caddisfly population. Ecology 64:1124-1135. DOI: 10.2307/1937823.

612 Mährlein M, Pätzig M, Brauns M, Dolman AM. 2016. Length-mass relationships for lake 613 macroinvertebrates corrected for back-transformation and preservation effects. 614 Hydrobiologia 768:37-50. DOI: 10.1007/s10750-015-2526-4. 
615 Martin EC, Gido KB, Bello N, Dodds WK, Veach A. 2016. Increasing fish taxonomic and 616 functional richness affects ecosystem properties of small headwater prairie streams. 617 Freshwater Biology 61:887-898. DOI: 10.1111/fwb.12752.

618 McCormick PV, Stevenson RJ. 1989. Effects of snail grazing on benthic algal community 619 structure in different nutrient environments. Journal of the North American Benthological $620 \quad$ Society 8:162-172. DOI: $10.2307 / 1467634$.

621 Melcher AH, Lautsch E, Schmutz S. 2012. Non-parametric methods - Tree and P-CFA - for the 622 ecological evaluation and assessment of suitable aquatic habitats: A contribution to fish psychology. Psychological Test and Assessment Modeling 54: 293-306.

Mewes D, Spielvogel S, Winkelmann C. 2017. RNA/DNA ratio as a growth indicator of stream 625 periphyton. Freshwater Biology 62:807-818. DOI: 10.1111/fwb.12903.

Meyer E. 1989. The relationship between body length parameters and dry mass in running water invertebrates. Archiv für Hydrobiologie 117:191-203.

Moulton TP, de Souza ML, Silveira RML, Krsulović FAM. 2004. Effects of ephemeropterans and shrimps on periphyton and sediments in a coastal stream (Atlantic forest, Rio de Janeiro, Brazil). Journal of the North American Benthological Society 23:868-881. DOI: 10.1899/0887-3593(2004)023<0868:EOEASO>2.0.CO;2. basin, France. Hydrobiologia 259:157-167. DOI: 10.1007/BF00006595.

634 Pagnucco KS, Remmal Y, Ricciardi A. 2016. An invasive benthic fish magnifies trophic 635 cascades and alters pelagic communities in an experimental freshwater system. Freshwater Science 35:654-665. DOI: 10.1086/685285. 
637 Peterson BJ, Deegan L, Helfrich J, Hobbie JE, Hullar M, Moller B, Ford TE, Hershey A, Hiltner 638 A, Kipphut G, Lock MA, Fiebig DM, McKinley V, Miller MC, Vestal JR, Ventullo R, 639 Volk G. 1993. Biological responses of a tundra river to fertilization. Ecology 74:653-672. 640 DOI: $10.2307 / 1940794$.

641 Pinder LCV. 1992. Biology of epiphytic Chironomidae (Diptera:Nematocera) in chalk streams. 642 Hydrobiologia 248:39-51. DOI: 10.1007/BF00008884.

643 Power ME. 1990a. Resource enhancement by indirect effects of grazers: armored catfish, algae, 644 and sediment. Ecology 71:897-904. DOI: 10.2307/1937361.

Power ME. 1990b. Effects of fish in river food webs. Science 250:811-814. DOI: 646 10.1126/science.250.4982.811.

647 Power ME, Dudley TL, Cooper SD. 1989. Grazing catfish, fishing birds, and attached algae in a 648 Panamanian stream. Environmental Biology of Fishes 26:285-294. DOI: 649 10.1007/BF00002465.

Power ME, Matthews WJ, Stewart AJ. 1985. Grazing minnows, piscivorous bass, and stream 651 algae: dynamics of a strong interaction. Ecology 66:1448-1456. DOI: 10.2307/1938007. depositional environment in a tropical stream: use of electricity for experimental exclusion. Canadian Journal of Fisheries and Aquatic Sciences 51:1443-1450. DOI: 10.1139/f94-144.

Pringle CM, Hamazaki T. 1997. Effects of fishes on algal response to storms in a tropical stream. Ecology 78:2432-2442. DOI: 10.2307/2265904.

R Development Core Team 2016. A language and environment for statistical computing. Vienna, 659 Austria: R Foundation for Statistical Computing. 
660 Reckendorfer W, Keckeis H, Tiitu V, Winkler G, Zornig H. 2001. Diet shifts in 0+ nase, 661 Chondrostoma nasus: Size-specific differences and the effect of food. Arch. Hydrobiol. $662 \quad$ Suppl 13512:425-440.

663 Rosemond AD, Mulholland PJ, Brawley SH. 2000. Seasonally shifting limitation of stream 664

665

666 periphyton: response of algal populations and assemblage biomass and productivity to variation in light, nutrients, and herbivores. Canadian Journal of Fisheries and Aquatic

667

668

669

670

671

672

673

674

675

676

677

678

679

680

681

682 Sciences 57:66-75.

Rosemond AD, Mulholland PJ, Elwood JW. 1993. Top-down and bottom-up control of stream periphyton: effects of nutrients and herbivores. Ecology 74:1264-1280. DOI: 10.2307/1940495

Rosemond AD, Pringle CM, Ramirez A. 1998. Macroconsumer effects on insect detritivores and detritus processing in a tropical stream. Freshwater Biology 39:515-523. DOI: 10.1046/j.1365-2427.1998.00301.x.

Schmedtje U, Colling M. 1996. Ökologische Typisierung der aquatischen Makrofauna. In: Bayerisches Landesamt für Wasserwirtschaft, ed. Informationsberichte des Bayerischen Landesamtes für Wasserwirtschaft. München: Bayerisches Landesamt für Wasserwirtschaft, pp. 543.

Schneck F, Schwarzbold A, Melo AS. 2013. Substrate roughness, fish grazers, and mesohabitat type interact to determine algal biomass and sediment accrual in a high-altitude subtropical stream. Hydrobiologia 711:165-173. DOI: 10.1007/s10750-013-1477-x.

Shapiro J, Wright DI. 1984. Lake restoration by biomanipulation: Round Lake, Minnesota, the first two years. Freshwater Biology 14:371-383. DOI: $10.1111 /$ j.13652427.1984.tb00161.x. 
683 Shelton JM, Samways MJ, Day JA, Woodford DJ. 2016. Are native cyprinids or introduced 684 salmonids stronger regulators of benthic invertebrates in South African headwater 685 streams?: Impact of alien Trout in streams. Austral Ecology 41:633-643. DOI: 686 10.1111/aec.12352.

687 688 interactions. Oecologia 72:1-7.

Sturt MM, Jansen MAK, Harrison SSC. 2011. Invertebrate grazing and riparian shade as controllers of nuisance algae in a eutrophic river. Freshwater Biology 56:2580-2593. DOI: $10.1111 / \mathrm{j} .1365-2427.2011 .02684 . x$.

Tarkowska-Kukuryk M. 2013. Periphytic algae as food source for grazing chironomids in a shallow phytoplankton-dominated lake. Limnologica - Ecology and Management of Inland Waters 43:254-264. DOI: 10.1016/j.limno.2012.11.004.

Ureche D, Ureche C, Nicoara M, Plavan G. 2010. The role of macroinvertebrates in diets of fish in River Dambovita, Romania. Verh. Internat. Verein. Limnol 30:1582-1586.

Vater M. 1997. Age growth of the undermouth Chondrostoma nasus in the Slovak stretch of the Danube river. Biologia (Bratislava) 52:653-651.

Vlach P, Švátora M, Dušek J. 2013. The food niche overlap of five fish species in the Úpoř brook (Central Bohemia). Knowledge and Management of Aquatic Ecosystems 411, 04:112. DOI: $10.1051 / \mathrm{kmae} / 2013070$.

Welch EB, Quinn JM, Hickey CW. 1992. Periphyton biomass related to point-source nutrient enrichment in seven New Zealand streams. Water Research 26:669-675. DOI: 10.1016/0043-1354(92)90243-W. 
705 Winkelmann C, Hellmann C, Worischka S, Petzoldt T, Benndorf J. 2011. Fish predation affects

706 the structure of a benthic community. Freshwater Biology 56:1030-1046. DOI:

707 10.1111/j.1365-2427.2010.02543.x.

708

709

710

711

712

713

714

715

716

717

718

719

720

721

722

723

724

725

726

Winkelmann C, Schneider J, Mewes D, Schmidt SI, Worischka S, Hellmann C, Benndorf J. 2014. Top-down and bottom-up control of periphyton by benthivorous fish and light supply in two streams. Freshwater Biology 59:803-818. DOI: 10.1111/fwb.12305.

Winkelmann C, Worischka S, Koop JHE, Benndorf J. 2007. Predation effects of benthivorous fish on grazing and shredding macroinvertebrates in a detritus-based stream food web. Limnologica - Ecology and Management of Inland Waters 37:121-128. DOI: 10.1016/j.limno.2006.11.001.

Wootton JT, Oemke MP. 1992. Latitudinal differences in fish community trophic structure, and the role of fish herbivory in a Costa Rican stream. Environmental Biology of Fishes 35:311-319. DOI: 10.1007/BF00001899.

Worischka S, Hellmann C, Berendonk TU, Winkelmann C. 2014. Fish predation can induce mesohabitat-specific differences in food web structures in small stream ecosystems. Aquatic Ecology 48:367-378. DOI: 10.1007/s10452-014-9490-3.

Worischka S, Koebsch C, Hellmann C, Winkelmann C. 2012. Habitat overlap between predatory benthic fish and their invertebrate prey in streams: the relative influence of spatial and temporal factors on predation risk: Habitat overlap and predation risk. Freshwater Biology 57:2247-2261. DOI: 10.1111/j.1365-2427.2012.02868.x.

Worischka S, Schmidt SI, Hellmann C, Winkelmann C. 2015. Selective predation by benthivorous fish on stream macroinvertebrates - The role of prey traits and prey 
727 abundance. Limnologica - Ecology and Management of Inland Waters 52:41-50. DOI:

$728 \quad$ 10.1016/j.limno.2015.03.004.

729 


\section{Figure 1 (on next page)}

Chlorophyll a concentration for controls and exclosures at the end of the experiments.

Chlorophyll a per area on accessible control tiles and fish exclosure tiles $(n=9)$ at the end of the three experiments performed at (A) low, $(B)$ intermediate and $(C)$ high densities of nase. Boxes: 75 and 25\%, whiskers: 95 and 5\%, dots: outliers. * Significant $(p<0.05)$. 

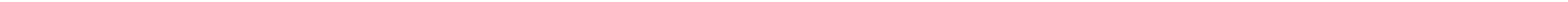


\section{Figure 2 (on next page)}

Ash-free dry mass for controls and exclosures at the end of the experiments.

Ash-free dry mass per area on accessible control tiles and fish exclosure tiles $(n=9)$ at the end of the three experiments performed at (A) low, (B) intermediate and (C) high densities of nase. Boxes: 75 and 25\%, whiskers: 95 and 5\%, dots: outliers. 

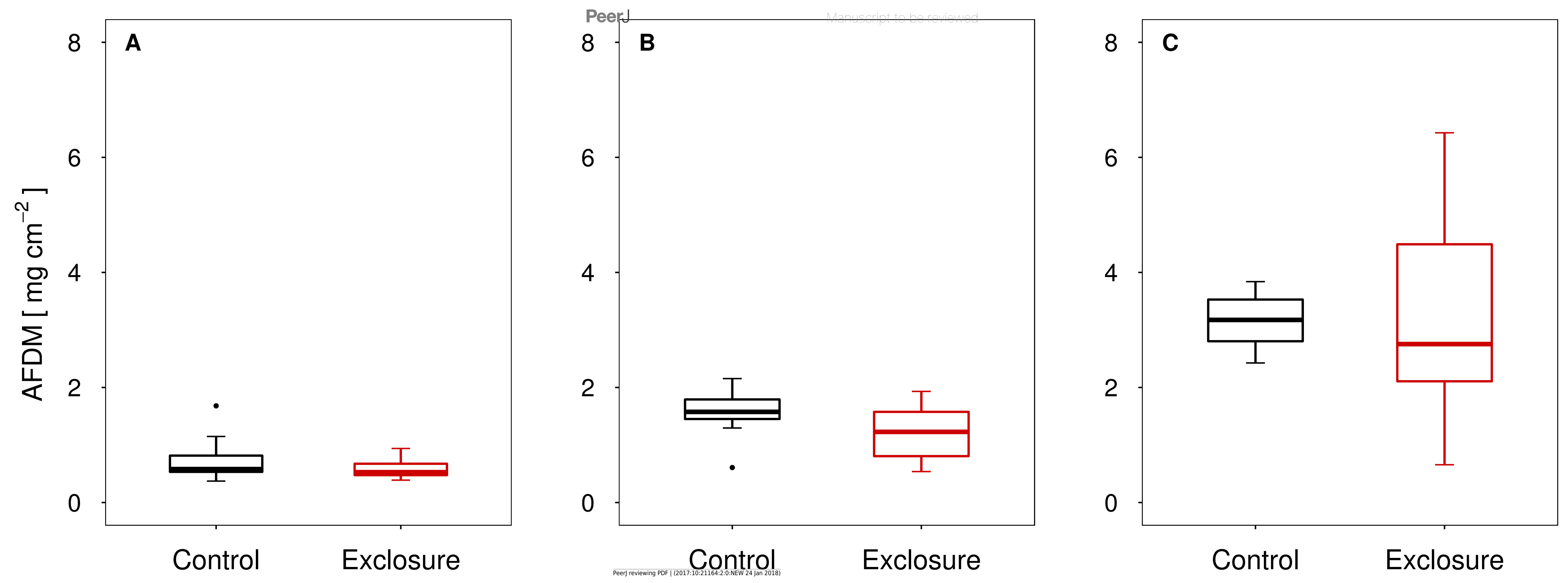


\section{Figure 3 (on next page)}

Biomass of invertebrate grazers for controls and exclosures at the end of the experiments.

Biomass of invertebrate grazers on accessible control tiles and fish exclosure tiles $(n \geq 8)$ at the end of the three experiments performed at (A) low, (B) intermediate and (C) high densities of nase. Boxes: 75 and 25\%, whiskers: 95 and 5\%, dots: outliers. * Significant ( $p<$ 0.05). 


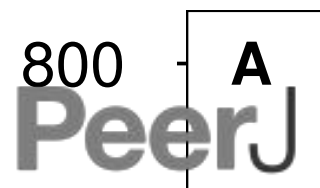

600

400

200

0
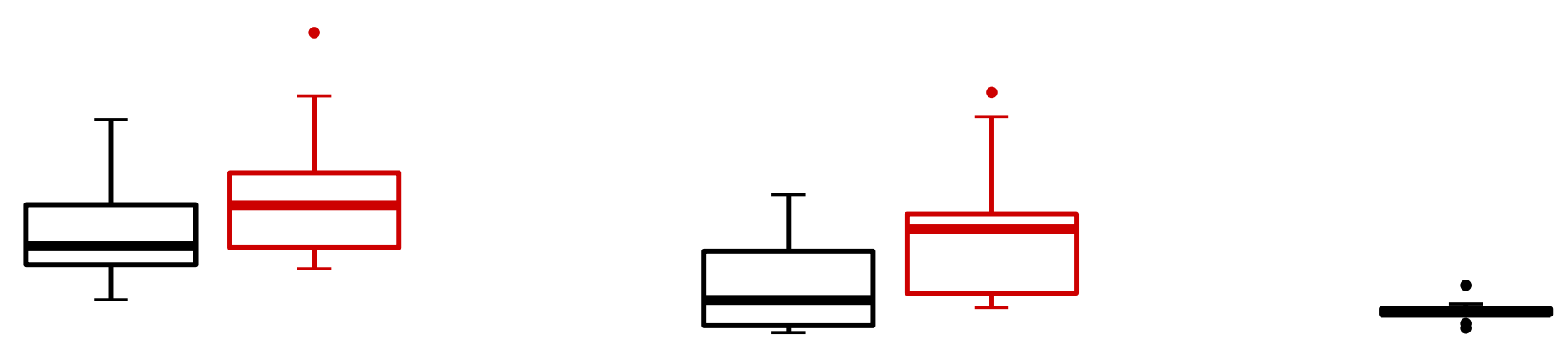

$800-\mathbf{B}$

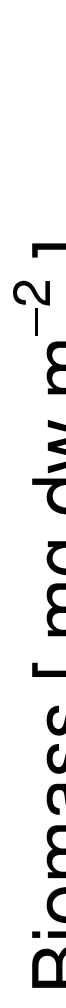

600

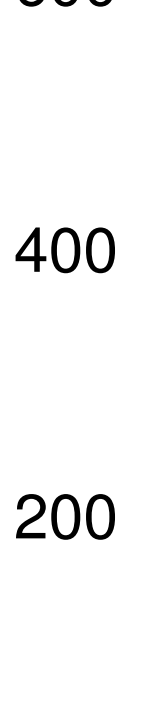

0

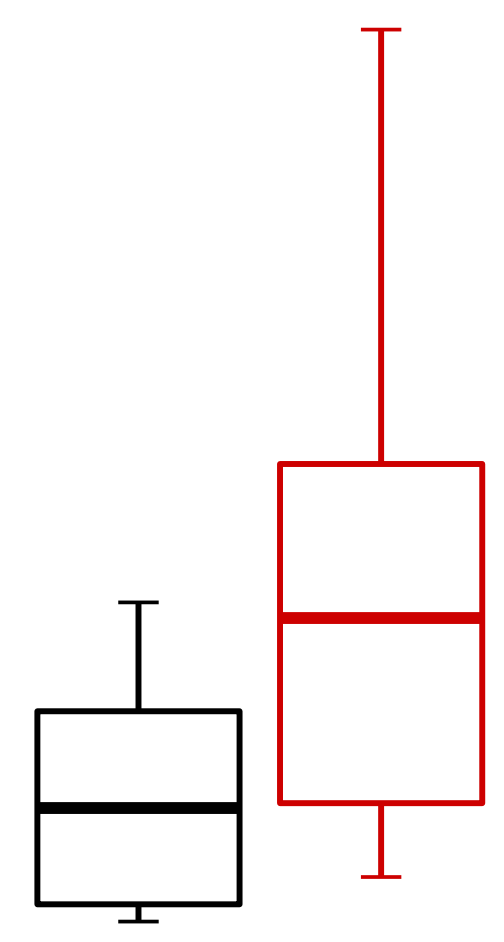

0

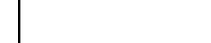

.
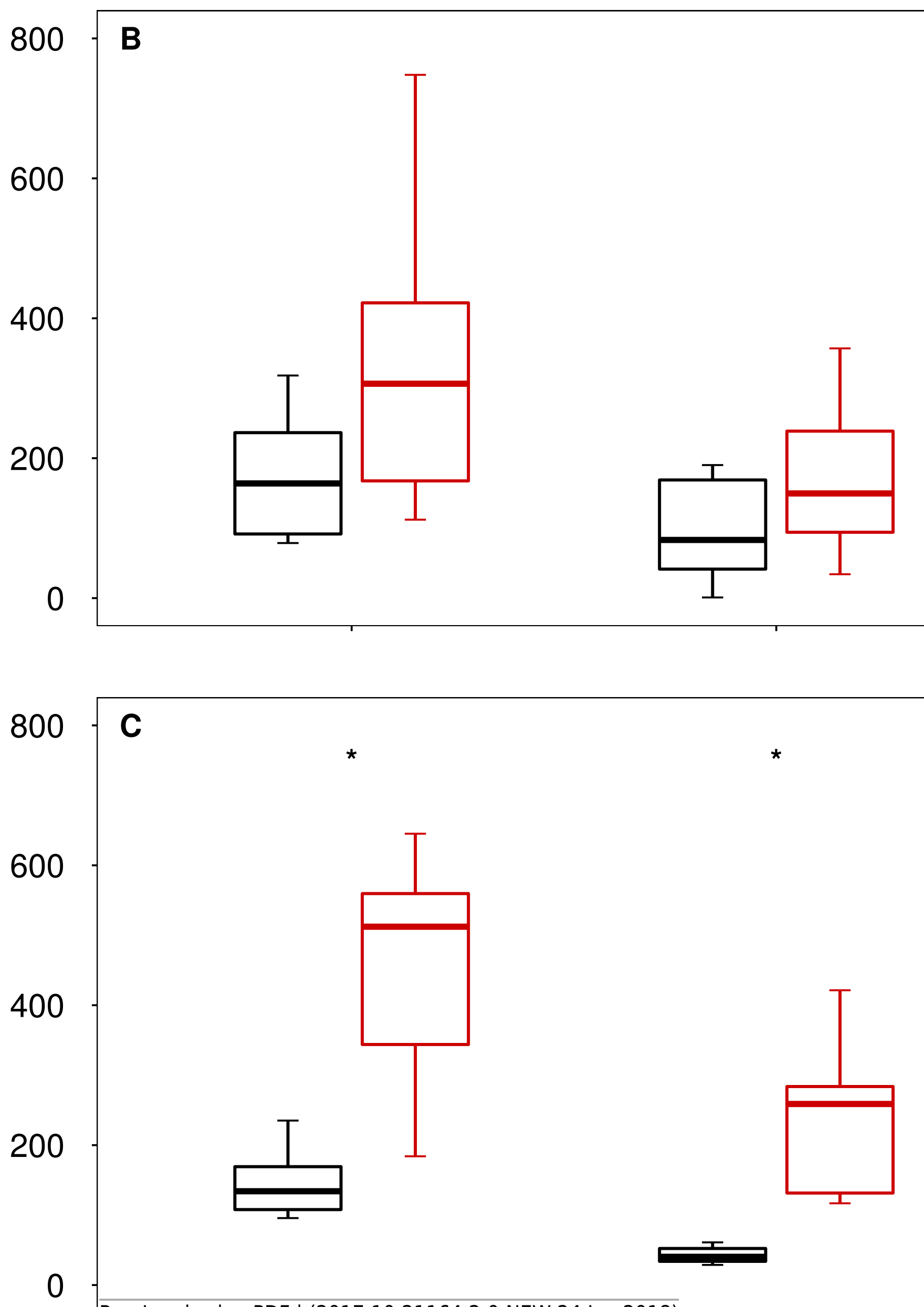

Peerf reviewing PDF | (2017:10:21164:2:0:NEW 24 Jan 2018) 


\section{Table $\mathbf{1}$ (on next page)}

Fish densities in the river in the three experiments.

Experiment I = low nase density; experiment II = intermediate nase density, and experiment III = high nase density. Values are the total number of individuals caught per $\mathrm{m}^{2}$ and calculated stock per m² (large fish: Ricker 1975; small fish: De Lury 1951, given only in case of significant regression coefficients). 


\begin{tabular}{|c|c|c|c|c|c|c|}
\hline & \multicolumn{2}{|c|}{ Experiment I } & \multicolumn{2}{|c|}{ Experiment II } & \multicolumn{2}{|c|}{ Experiment III } \\
\hline & \multicolumn{2}{|c|}{ Site A } & \multicolumn{2}{|c|}{ Site B } & \multicolumn{2}{|c|}{ Site B } \\
\hline & \multicolumn{2}{|c|}{ July 2013} & \multicolumn{2}{|c|}{ June 2013} & \multicolumn{2}{|c|}{ July 2016} \\
\hline Fish & Catch & Stock & Catch & Stock & Catch & Stock \\
\hline$>15 \mathrm{~cm}$ & [ind. $\mathrm{m}^{-2}$ ] & [ind. $\mathrm{m}^{-2}$ ] & [ind. $\mathrm{m}^{-2}$ ] & [ind. $\mathrm{m}^{-2}$ ] & [ind. $\mathrm{m}^{-2}$ ] & [ind. $\mathrm{m}^{-2}$ ] \\
\hline Nase & 0.005 & 0.004 & 0.019 & 0.033 & 0.198 & 0.276 \\
\hline Chub & 0.003 & 0.005 & 0.003 & 0.005 & 0.032 & 0.062 \\
\hline Dace & 0.004 & 0.005 & 0.003 & 0.010 & 0.016 & 0.082 \\
\hline Other & 0.005 & 0.012 & 0.003 & 0.007 & 0.036 & 0.076 \\
\hline Total & 0.016 & 0.026 & 0.027 & 0.055 & 0.281 & 0.495 \\
\hline \multicolumn{7}{|l|}{$<15 \mathrm{~cm}$} \\
\hline Bullhead & 0.51 & & 0.31 & 0.84 & 0.27 & 0.4 \\
\hline Minnow & 0.48 & & 0.68 & & 0.25 & 0.4 \\
\hline Stone loach & 0.85 & 1.23 & 0.52 & 1.49 & 0.91 & 2.0 \\
\hline Total & 1.83 & & 1.51 & & 1.43 & 2.8 \\
\hline
\end{tabular}

1 


\section{Table 2 (on next page)}

Mean values of environmental parameters for controls and exclosures in the three experiments.

Mean values ( \pm SD) of water depth, light supply (PAR) and current velocity on accessible control tiles and fish exclosure tiles $(n=9)$ averaged over the experiment duration (number of measurements, $n \geq 3$ ). 
1

\begin{tabular}{lcccccc}
\multirow{2}{*}{ Nase density } & \multicolumn{2}{c}{$\begin{array}{c}\text { Water depth } \\
{[\mathrm{cm}]}\end{array}$} & \multicolumn{2}{c}{ PAR } & \multicolumn{2}{c}{$\begin{array}{c}\text { Current velocity } \\
{\left[\mu \mathrm{m} \mathrm{s}^{-1}\right]}\end{array}$} \\
\cline { 2 - 7 } & Exclosure & Control & Exclosure & Control & Exclosure & Control \\
\hline Low (I) & $21.9 \pm 10.3$ & $20.7 \pm 11.5$ & $846.1 \pm 696.2$ & $979.1 \pm 849.1$ & $0.19 \pm 0.04$ & $0.20 \pm 0.08$ \\
Intermediate (II) & $29.3 \pm 13.5$ & $27.5 \pm 9.8$ & $153.6 \pm 61.7$ & $169.4 \pm 78.0$ & $0.27 \pm 0.12$ & $0.29 \pm 0.08$ \\
High (III) & & & $127.4 \pm 45.3$ & $111.8 \pm 41.4$ & $0.33 \pm 0.06$ & $0.27 \pm 0.06$
\end{tabular}




\section{Table 3(on next page)}

Pearson correlation coefficients between biotic response variables and environmental factors (water depth, light supply PAR and current velocity).

*Significant $(p<0.05)$. 
1

\begin{tabular}{|c|c|c|c|c|c|c|c|c|}
\hline & \multicolumn{3}{|c|}{$\begin{array}{l}\text { Low nase density } \\
\text { (I) }\end{array}$} & \multicolumn{3}{|c|}{$\begin{array}{l}\text { Intermediate nase density } \\
\text { (II) }\end{array}$} & \multicolumn{2}{|c|}{$\begin{array}{l}\text { High nase density } \\
\text { (III) }\end{array}$} \\
\hline & $\begin{array}{l}\text { Water } \\
\text { depth }\end{array}$ & PAR & $\begin{array}{l}\text { Current } \\
\text { velocity }\end{array}$ & $\begin{array}{l}\text { Water } \\
\text { depth }\end{array}$ & PAR & $\begin{array}{l}\text { Current } \\
\text { velocity }\end{array}$ & PAR & $\begin{array}{l}\text { Current } \\
\text { velocity }\end{array}$ \\
\hline \multicolumn{9}{|l|}{ Exclosure } \\
\hline Chl $a$ & $0.89 *$ & -0.31 & 0.58 & 0.02 & -0.36 & $0.75^{*}$ & 0.60 & 0.24 \\
\hline AFDM & 0.62 & 0.03 & 0.60 & -0.07 & -0.12 & $0.72 *$ & 0.62 & 0.23 \\
\hline Grazer biomass & -0.36 & $0.75 *$ & 0.44 & -0.57 & 0.48 & 0.58 & 0.57 & 0.18 \\
\hline \multicolumn{9}{|l|}{ Control } \\
\hline Chl $a$ & $0.72 *$ & -0.15 & 0.50 & -0.23 & 0.44 & -0.22 & 0.45 & 0.51 \\
\hline AFDM & 0.64 & 0.03 & 0.51 & -0.03 & 0.21 & -0.36 & 0.44 & 0.44 \\
\hline Grazer biomass & $-0.83^{*}$ & $0.68 *$ & $0.73 *$ & -0.32 & 0.41 & 0.40 & -0.02 & 0.48 \\
\hline
\end{tabular}

